ORIGINAL ARTICLE / ARTIGO ORIGINAL

\title{
Genotypes distribution of human papillomavirus in cervical samples of Ecuadorian women
}

\author{
Distribuição dos genótipos de papilomavirus humano em \\ amostras de colo do útero de mulheres equatorianas
}

\author{
Gustavo David García Muentes', Lindsay Karen García Rodríguez', Ramiro Israel Burgos Galarraga', \\ Franklin Almeida Carpio', Juan Carlos Ruiz Cabezas'
}

\begin{abstract}
Introduction: Human papillomavirus (HPV) is considered a necessary causative agent for developing oropharyngeal, anal and cervical cancer. Among women in Ecuadorian population, cervical cancer ranks as the second most common gynecological cancer. Not many studies about HPV burden have been published in Ecuador, and genotypes distribution has not been established yet. The little data available suggest the presence of other genotypes different than 16 and 18. Objectives: In the present study, we attempt to estimate the prevalence of HPV 16, HPV 18 and other 35 genotypes among Ecuadorian women undergoing cervical cancer screening. The overall prevalence of HPV infection was also estimated. Methods: Routine cervical samples were analyzed using Linear Array ${ }^{\circledR}$ HPV Genotyping test (Roche). Results: A total of 1,581 cervical samples obtained from Ecuadorian women undergoing cervical cancer screening were included in this study. HPV DNA was detected in 689 cervical samples (43.58\%). Of these samples, $604(38.20 \%)$ were positive for a single HPV genotype, while another 85 (5.37\%) samples were positive for multiple HPV types. Genotype 16 (5.50\%) resulted in the most frequently detected type in both single and multiple infections. HPV 33 (4.55\%) and HPV $11(3.80 \%)$ occupied the second and the third place in frequency among all detected genotypes. Conclusions: Viral genotypes different from HPV 16 and HPV 18 are frequently detected among Ecuadorian women. The overall prevalence of HPV resulted higher than the one reported in other South American countries with a greater burden in the second and third decades of life.
\end{abstract}

Keywords: Human papillomavirus. Ecuador. Uterine cervical neoplasms. Polymerase chain reaction.

'Sociedad de Lucha Contra el Cáncer (SOLCA) - Provincia del Guayas, Guayaquil Ecuador; Universidad de Especialidades Espíritu Santo - Samborondón, Ecuador.

Corresponding author: Juan Carlos Ruiz Cabezas. Sociedad de Lucha Contra el Cáncer. Avenida Pedro Menéndez Gilbert S/n y Atahualpa Chávez, Provincia del Guayas, Guayaquil Ecuador. E-mail: jruiz@solca.med.ec

Conflict of interests: nothing to declare - Financial support: none. 
RESUMO: Introdução: O papilomavírus humano (HPV) é considerado agente causador necessário para o desenvolvimento de câncer da orofaringe, do colo do útero e anal. Na população feminina do Equador, o câncer de colo do útero é o segundo câncer ginecológico mais comum. No Equador, o número de estudos publicados sobre o HPV é pequeno, e a distribuição de genótipos ainda não foi estabelecida. Os dados limitados sugerem a presença de outros genótipos diferentes dos tipos 16 e 18. Objetivos: No presente estudo, foi estimada a prevalência de HPV 16, HPV 18 e outros 35 genótipos entre as mulheres equatorianas submetidas ao exame de rastreamento para câncer do colo do útero. Métodos: Amostras cervicais de rotina foram analisadas pelo (método) Linear Array ${ }^{\circledR} \mathrm{VPH}$ (Roche). Resultados: Foram incluídas neste estudo 1.581 amostras cervicais de mulheres equatorianas. O HPV foi detectado em $689(43,58 \%)$ amostras cervicais. Destas, 604 (38,20\%) foram positivas para somente um genótipo de HPV, enquanto $85(5.37 \%)$ amostras foram positivas para vários tipos. O genótipo $16(5,50 \%)$ foi a variante mais frequentemente detectada nos casos com infecção única ou múltipla. HPV 33 (4,55\%) e HPV 11 (3,80\%) ficaram, respectivamente, em segundo e terceiro lugar em frequência entre todos os genótipos detectados. Conclusões: Outros genótipos virais de alto risco diferentes do que HPV 16 e HPV 18 são frequentemente detectados entre as mulheres equatorianas. A prevalência global de infecção cervical pelo HPV foi maior do que a observada em outros países da América do Sul.

Palavras-chave: Papillomavirus humano. Equador Neoplasias do colo do útero. Reação em cadeia da polimerase.

\section{INTRODUCTION}

Human papillomavirus (HPV) is considered a necessary causative agent for developing cervical cancer and it is also the most common sexually transmitted viral pathogen ${ }^{1}$. More than $230 \mathrm{HPV}$ genotypes have been identified by DNA sequencing from which approximately 40 infect the anogenital region ${ }^{2}$. At present, only 12 of these genotypes (16, 18, 31, 33, 35, $39,45,51,52,56,58,59)$ are recognized as high risk types by the International Agency for Research on Cancer, part of the World Health Organization ${ }^{3}$. From these genotypes, HPV 16 and 18 are described as the most prevalent, involving about $70 \%$ of cervical cancer cases ${ }^{4}$. Other genotypes, as HPV 68, were recently passed from group I to group IIA of biological carcinogens and reclassified as probably carcinogenic 5 .

Not many studies about the epidemiology of HPV infection have been published in Ecuadorian population. Publications by local groups about HPV burden suggest the presence of many HPV types different from types 16 and 18.

One of these studies, conducted by Tornesello et al. in 2008, mentioned HPV 16 as the most commonly detected genotype followed by HPV $81^{6}$.

A second study performed in 2009 by Brown et al. in Santa Elena Province showed a disproportional prevalence of HPV in Ecuador. This last publication indicates HPV types $16,52,58$ and 59 as the most prevalent among high risk types, and HPV 62, 71, 72 and 83 as the most frequent among low risk types ${ }^{7}$.

In the same year, a second study by González and Sánchez performed in anogenital samples obtained from Ecuadorian women living in Quito referred genotypes 6 and 66 as the most frequently identified ${ }^{8}$. 
With regard to the impact of HPV vaccination, there is no available information among Ecuadorian women. Multiple worldwide follow up studies indicate that vaccines prevent cervical infection by some high risk genotypes different from 16 and 18, including HPV types $31,33,45,52,58^{9-11}$.

As the presence of these last genotypes could be underestimated, it was the aim of the present study to estimate the prevalence of HPV 16, HPV 18 and other 35 high risk and low risk genotypes among Ecuadorian women attended as outpatient at SOLCA Hospital using Roche reverse line assay.

\section{MATERIALS AND METHODS}

\section{CLINICAL SAMPLES}

Cervical swabs obtained from 1,581 Ecuadorian women from different urban areas aged 20 to 70 years were included in this cross-sectional study. The samples were collected in PreservCyt ${ }^{\circledR}$ liquid media at SOLCA gynecological outpatient service from January 2008 until December 2013. All of the collected swabs were obtained from patients previously diagnose with cervical dysplasia and derived from other Institutions due to their lack of infrastructure to perform DNA analysis. All the samples were finally sent to SOLCA Molecular Biology laboratory.

\section{DNA EXTRACTION}

DNA extraction was performed with AmpliLute Liquid Media Extraction Kit (Roche), according to manufacturer's instructions. Purity of DNA was measured by spectrophotometry.

\section{GENOTYPE IDENTIFICATION}

HPV types were identified using Linear Array ${ }^{\circledR}$ HPV Genotyping test (Roche), allowing the characterization of $37 \mathrm{HPV}$ genotypes, including 16, 18, 26, 31, 33, 35, 39, 45, 51, $52,53,56,58,59,66,67,68,69,70,73,82$, IS39, 6, 11, 40, 42, 54, 55, 61, 62, 64, 71, 72, 81, 83,84 and $\mathrm{CP} 6108^{12}$. First, purified DNA was used for specific conventional PCR using PGMY09/PGMY11 set of primers and performed in 9700 Applied Biosystems ${ }^{\circledR} /$ GeneAmp $^{\circledR}$ thermal cycler. After a chemical denaturation of PCR product, a process of hybridization with specific probes located at each reverse line strip was performed followed by consecutive washings to eliminate unspecifically bound molecules. To permit the detection of HPV hybridized DNA, a conjugate consisting of streptavidin alkaline phosphatase was added to biotinylated primers associated with PCR products. After addition of conjugate, new washes were performed previously to a final step consisting of the aggregation of 
substrate that generates a bluish band appearance due to color reaction in the presence of HPV corresponding genotype.

The quality and sufficiency of DNA was evaluated amplifying a human beta globin gene endogenous region complementary to two different probes located at the end of each reverse line strip. Both bands for beta globin gene detection were present at every included case result.

\section{DATA ANALYSIS}

HPV test results were considered as positive or negative according to the presence of genotype specific bluish band at each reverse line strip. The overall and type-specific prevalence of HPV infection were estimated. Informed consent was not required as the data obtained came from routinely performed diagnostic procedures avoiding the inclusion of personal information. This study was exempt from an Ethic Committee approval due to the internal hospital policies.

\section{RESULTS}

A total of 1,581 samples were included in this study. All cervical samples were qualified as sufficient and could be analyzed. Of the samples tested, 689 resulted positive for HPV with an overall prevalence of $43.58 \%$. HPV 16 was the most commonly detected type, with 87 cases $(5.50 \%)$, followed by HPV 33, with 72 cases (4.55\%); genotype 66 (2.59\%) resulted in the fifth most commonly detected genotype; HPV $11(3.80 \%)$ was the most frequently detected low risk type (Figure 1). In 85 cases, multiple HPV genotypes were detected, including 67 in which 2 genotypes were detected, 11 in which 3 genotypes were detected, and 7 in which 4 genotypes were detected.

The prevalence of other high risk types, including 31, 33, 35, 39, 45, 51, 52, 56, 58 and 59, was higher than HPV 16 and HPV 18 (Table 1).

Among multiple infections, HPV 16 was detected in 16 samples, while HPV 18 in four. No combination was detected including HPV 16 and HPV 18 at the same time.

HPV detection frequency was higher among women in the group of 30 to 39 years old with a prevalence of $37.97 \%$ followed by the group of 20 to 29 years old with lower prevalence of $31.39 \%$.

\section{DISCUSSION}

Only a few studies on the burden of HPV genotypes prevalence have been conducted among Ecuadorian women, and we must remark that until now this work represents the biggest one.

Most of the samples collected by our Gynecology service came from Institutions different from ours with specific request of HPV genotyping analysis. This situation 
constitutes the biggest study limitation as the patients were derived as diagnosed with cervical dysplasia using CIE10 general code and without specifying the detected cytological abnormalities. This fact does not permit to classify cervical lesions for further correlation analysis. Despite of that, we have focused mainly in estimating the prevalence and distribution of HPV genotypes, classifying all the samples only as suspicious of viral infection.

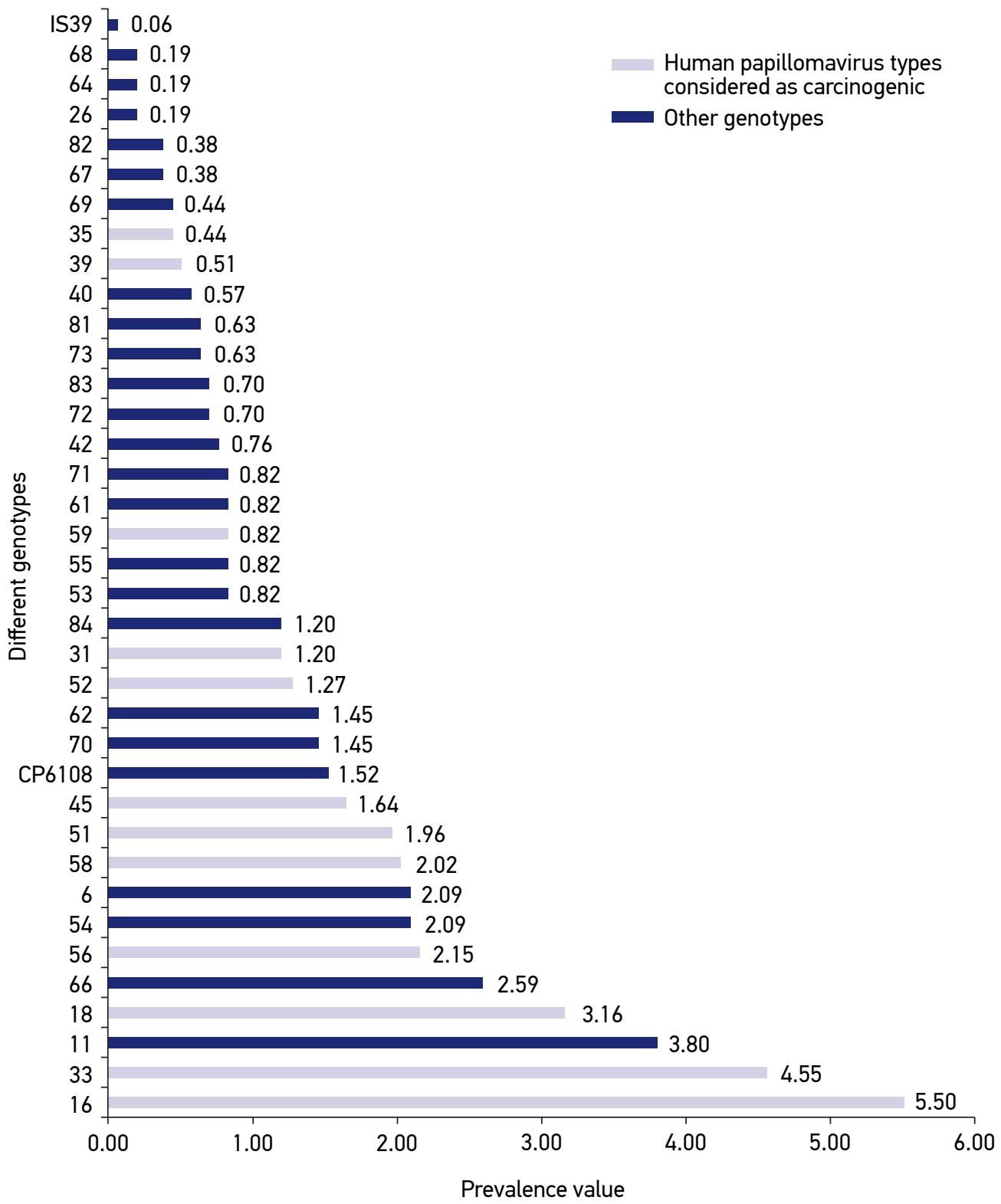

Figure 1. Human papillomavirus prevalence by each detected genotype. 
Table 1. Prevalence of human papillomavirus among 1,581 samples.

\begin{tabular}{|c|c|c|}
\hline Result of Linear array & Samples & Prevalence (\%) \\
\hline HPV $16^{a}$ & 87 & 5.50 \\
\hline HPV $18^{a}$ & 50 & 3.16 \\
\hline HPV Other high risk ${ }^{a, b}$ & 262 & 16.57 \\
\hline Rest of HPV & 290 & 18.34 \\
\hline HPV negative & 892 & 56.42 \\
\hline Total & 1581 & 100.00 \\
\hline
\end{tabular}

The prevalence of HPV (43.58\%) among the studied population resulted similar than reported in Colombia (44.30\%) among HIV negative patients, but higher than values estimated among Brazilian (29.90\%) and Peruvian women $(34.49 \%)^{13-15}$.

Not very different results were obtained for HPV 16 if we compare our data to previous Latin American publications ${ }^{16}$. Differing from the previous mentioned studies performed among Ecuadorian women, the second most common genotype identified was HPV 33. In the case of low risk types, HPV 11 appeared to be more frequent than HPV 6.

Among the studied women, HPV infection resulted higher during the second and third decades of life, result that differs from previous published data and that could be explain by the fact that the samples included on this study were collected from daily routine analysis without more complex design or inclusion criteria.

\section{CONCLUSION}

All together the frequency of other high risk HPV genotypes resulted higher than HPV 16 and HPV 18. In the case of HPV 16, the obtained frequency was similar to reported in other regions. Differing from previous Ecuadorian studies, HPV 33 occupies the second place within all detected genotypes. HPV overall prevalence resulted higher than reported in other Latin American countries, including Peru and Brazil.

\section{ACKNOWLEDGMENTS}

We acknowledge our technical personnel at Molecular Biology Department. 


\section{REFERENCES}

1. Sanjose S, Castellsague X, Clifford G, Bruni L, Muñoz N, Bosh FX. Worldwide prevalence and genotypes distribution of cervical human papillomavirus DNA in women with normal cytology: a meta-analysis. Lancet Infect Dis 2007; 7: 453-459.

2. De Oliveira Carvalho N, Mendez del Castillo D, Perone C, Juanário JN, Melo VH, Brasileiro G. Comparison of HPV genotyping by type-specific PCR and sequencing. Mem Inst Oswaldo Cruz 2010; 105:73-78.

3. Bouvard V, Baan R, Straif K, Grosse Y, Secretan B, El Ghissassi F, et al. A review of human carcinogens-Part B: biological agents. Lancet Oncol 2009; 10(4): 321-322.

4. Smith J, Lindsay L, Hoots B, Keys J, Franceschi S, Winer R, et al. Human Papillomavirus type distribution in invasive cervical cancer and high grade cervical lesions: A meta-analysis update. Int J Cancer 2007; 121, 621-622.

5. Torres M, Fraile L, Echevarria JM, Hernandez Novoa B, Ortiz M. Human Papillomavirus (HPV) genotyping and application in routine laboratory testing. Open Virol J 2012; 6: 144-150.

6. Tornesello ML, Buonaguro L, Izzo S, Lopez G, Vega $\mathrm{X}$, Maldonado Reyes CF, et al. A pilot study on the distribution of human papillomavirus genotypes and HPV 16 variants in cervical neoplastic lesions from Ecuadorian women. J Med Virol, 2008; 80(11): 1959-65

7. Brown CR, Leon ML, Munoz K, Fagioni A, Amador LG, Frain B. Human papillomavirus infection and its association with cervical displasia in Ecuadorian women attending a private cancer screening clinic. Braz J Med Biol Res 2009; 42: 629-636.

8. González-Andrade F, Sánchez D. HPV genotyping in anogenital abnormal samples of Ecuadorian women. Cancer Biomark 2009; 5(4): 225-232.
9. Riethmuller D, Jacquard AC, St Guily JL, Aubin F, Carcopino X, Pradat P, et al. Potential impact of a nonavalent HPV vaccine on the occurrence of HPV-related diseases in France. BMC Public Health 2015;15: 453.

10. HPV vaccine works against nine viral types. Cancer Discov 2014; 4(1): OF2.

11. Serrano B, Alemany L, Tous S, Bruni L, Clifford GM, Weiss T, et al. Potential impact of a nine-valent vaccine in human papillomavirus related cervical disease. Infect Agent Cancer 2012; 7(1): 38.

12. Ashley Arney MT, Bennett KM. Molecular diagnostics of Human Papillomavirus. Lab Med 2010; 41(9): 523-30.

13. Camargo M, Soto S, Munoz M, Sanchez R, Pena D, Pineda A, et al. Human papillomavirus detection in women with and without human immunodeficiency virus infection in Colombia. BMC Cancer. 2014; 18: 14:451.

14. Entiauspe L, Silveira M, Nunes E, Basgalupp S, Stauffert D, Delagostin O, et al. High incidence of oncogenic HPV genotypes found in women from Southern Brazil. Braz J Microbiol 2014; 45(2): 689-94.

15. Iwasaki R, Galvez F, Arias Stella J, Arias Stella J. Prevalence of high risk human papillomavirus by cobas 4800 HPV test in urban Peru. Braz J Infect Dis 2014; 18(5): 469-472.

16. Sepúlveda-Arias JC, Álvarez-Aldana A. Burden of Human Papillomavirus Infection in Latin America. Intech Open 2013; 360-380-17.

Received on: 11/11/2014

Final version presented on: 11/03/2015

Accepted on: 12/11/2015 